\title{
AJANKOHTAISTA
}

\section{Gerontologinen sosiaalityö erityisen tuen tarpeisiin vastaamassa}

Iäkkäiden vaikeat elämäntilanteet ovat olleet viime vuosina monella tapaa esillä julkisessa keskustelussa. Ikääntymisen, eläköitymisen ja sairauksien sekä sosiaalisten verkostojen todennäköisen pienentymisen takia sosiaaliset ongelmat vanhuuden elämänvaiheessa voivat kärjistyä. Näin ollen gerontologiselle sosiaalityölle on ikääntyvässä yhteiskunnassa erityinen tarve, ja sen asema on vahvistumassa koulutuksessa ja tutkimuksessa niin Suomessa kuin muualla Euroopassa (Lee \& Waites 2006; Ray \& Phillips 2012; Seppänen 2016). Gerontologinen sosiaalityö pyrkii vahvistamaan ikääntyneiden hyvinvointia edistäviä olosuhteita, yhteisöjen toimivuutta ja ikääntyneiden toimintakykyisyyttä (Seppänen 2006). Se etsii silti vielä paikkaansa osana palvelujärjestelmää, ja sen saatavuudessa on suuria alueellisia eroja. Erityisesti joissakin suuremmissa kunnissa on gerontologiseen sosiaalityöhön erikoistuneita työntekijöitä, kun taas toisissa kunnissa gerontologinen sosiaalityö sijoittuu osaksi muuta sosiaalityötä tai erityisosaamista siihen ei ole lainkaan (Kröger ym. 2007; Pajunen ym. 2009).

Ohjautuminen gerontologiseen sosiaalityöhön sekä erilaisten riskitekijöiden ja riskiryhmien tunnistaminen on osin sattumanvaraista (Kehusmaa ym. 2018). Näin siitäkin huolimatta, että palveluiden saavutettavuutta on pyritty turvaamaan keskitetyillä asiakas- ja palveluohjausyksiköillä eli niin sanotulla yhden luukun periaatteella (STM 2020a). Viimeaikaiset ikääntyneiden palveluja kehittävät kärkihankkeet ovatkin keskittyneet neuvonnan, ohjauksen ja keskittämisen näkökulmiin (Ristolainen ym. 2018), mutta sosiaalihuoltolain toimeen- pano erityisen tuen tarpeen kohdalla on jäänyt vähemmälle huomiolle.

Sosiaalityöntekijältä vaaditaan kykyä työskennellä kompleksisten elämäntilanteiden parissa sekä ymmärtää erilaisten sosiaalisten määreiden yhteisvaikutusten merkitys (Ray ym. 2015). Nämä ilmiöt ovat usein läsnä erityistä tukea tarvitsevien vanhojen ihmisten tilanteissa. Ammatillisen tietoperustan rakentumiseen tarvitaan ajankohtaista tutkimustietoa. Muutamissa aiemmissa kehittämishankkeissa on kehitetty gerontologisen sosiaalityön menetelmiä (ks. Liikanen 2007; Antikainen-Juntunen 2014; Soukiala 2015; Autio \& Soukiala 2016), mutta aihepiiriä koskeva tutkimus on tähän mennessä ollut hyvin vähäistä.

Uusi tutkimushanke vastaa gerontologisen sosiaalityön haasteisiin

Sosiaalityön yliopistotasoiseen tutkimukseen oli mahdollista hakea ensimmäistä kertaa valtion tutkimusrahoitusta sosiaalihuoltolakiin syyskuussa 2020 tehdyn muutoksen myötä (Sosiaalihuoltolaki 60 c $§ 1301 / 2014$; STM 2020b). Terveydenhuoltoa koskevassa tutkimustoiminnassa vastaavanlainen, terveydenhuoltolakiin perustuva rahoitusinstrumentti on ollut käytössä jo pidempään (61- 63 § 1326/2010). Sosiaalihuoltolain muutoksen tavoitteena on sosiaalihuollon tutkimusperustaisuuden ja käytäntöjen vaikuttavuuden vahvistaminen. Yksi ensimmäisessä haussa rahoituksen saaneista hankkeista on "Gerontologinen sosiaalityö erityisen tuen tarpeisiin vastaamassa (GERIT)” -tutkimushankkeemme, joka 
keskittyy vanhenemisen ja huono-osaisuuden teemoihin.

Vuoden 2021 alussa käynnistyneessä GERIT-hankkeessa tarkastellaan vanhojen ihmisten vaikeita elämäntilanteita ja erityisen tuen tarpeita sekä eri toimijoiden työskentelyä heidän kanssaan. Tutkimus jakautuu kolmeen osaan, joita toteuttavat yhteistyössä Helsingin yliopisto, Itä-Suomen yliopisto sekä Lapin yliopisto. Itä-Suomen yliopistossa tarkastellaan gerontologista sosiaalityötä asiakas- ja palveluohjausprosessien näkökulmasta. Lapin yliopistossa erityisen tuen tarpeessa olevien vanhojen ihmisten elämäntilanteita tarkastellaan erityisesti talouden näkökulmasta. Helsingin yliopistossa tutkitaan, miten kasautuneet hyvinvointiongelmat ja erityisen tuen tarve ilmenevät gerontologisen sosiaalityön asiakkaiden elämässä, sekä työkäytäntöjä, joilla niihin voidaan sosiaalityön keinoin vaikuttaa. Tutkimusryhmämme on monitieteinen, sisältäen muun muassa sosiaalityön, sosiaalipolitiikan ja sosiaaligerontologian tieteenalojen osaamista. Monella tutkijalla on myös gerontologisen sosiaalityön käytännön kokemusta.

\section{Huono-osaisuus ja erityisen tuen tarve vanhuudessa}

GERIT-hankkeessa olemme kiinnostuneita siitä, miten erilaiset elämäntilanteet tuottavat erityisen tuen tarvetta vanhoilla ihmisillä, millä tavoin tuen tarpeita tunnistetaan erilaisissa toimintaympäristöissä sekä miten erityisen tuen tarpeessa olevat vanhat ihmiset ohjataan gerontologisen sosiaalityön palveluihin. Lisäksi tarkastelemme, millä tavoin gerontologisen sosiaalityön työmenetelmissä huomioidaan moniulotteinen huono-osaisuus. Tutkimuksen keskiössä ovat ikääntyneiden vaikeat elämäntilanteet ja niihin kytkeytyvät erilaiset tuen tarpeet, joita tulee yhä enemmän esille sosiaalihuoltolakiin perustuvien huoli-ilmoitusten kautta. Joillakin ikääntyneillä elämäntilanne voi olla monimutkaistunut sellaisella tavalla, että heidät voidaan nähdä sosiaalihuoltolain
(1301/2014, §3) mukaisesti erityistä tukea tarvitsevana eli

henkilönä, jolla on erityisiä vaikeuksia hakea ja saada tarvitsemiaan sosiaali- ja terveyspalveluja kognitiivisen tai psyykkisen vamman tai sairauden, päihteiden ongelmakäytön, usean yhtäaikaisen tuen tarpeen tai muun vastaavan syyn vuoksi ja jonka tuen tarve ei liity korkeaan ikään siten kuin vanhuspalvelulaissa säädetään.

Ikääntyneiden kanssa tehtävässä sosiaalityössä kohdataan usein kasautuneita ongelmia sekä eri tavoin ilmeneviä psykososiaalisia tarpeita. Esimerkiksi yksinäisyyden ja turvattomuuden kokemukset voivat olla joillekin jatkuvia, hyvinvointia heikentäviä ongelmia (Tiilikainen 2019). Sosiaalisiin verkostoihin voi liittyä vaikeita ristiriitoja, joista eräs vaiettu ongelma on monissa eri muodoissa ilmenevä kaltoinkohtelu (Laaksonen 2010; Yon ym. 2017). Myös köyhyys jää yleisyydestään huolimatta usein piiloon ikääntyneiden kanssa työskenneltäessä (Vaalavuo 2018; Ahonen ym. 2019). Vanhojen ihmisten moniulotteinen huono-osaisuus on viime aikoina saanut myös uusia muotoja, $\mathrm{ku}^{-}$ ten digitaalinen syrjäytyminen, riittämätön apu ja hoiva (Kröger ym. 2019; Pirhonen ym. 2020), sosiaalisten verkostojen täydellinen puute sekä erilaiset asumiseen liittyvät ongelmat, kuten esimerkiksi luteet ja raivaussiivouksen tarve (Helsingin kaupunki 2019). Lisäksi palvelujärjestelmän monimutkaisuus ja palveluiden siirtyminen verkkoon tai fyysisesti etäälle vaikeuttavat avun saantia etenkin maaseudulla, missä etäisyydet palveluihin voivat olla pitkät. Nämä erilaiset sosiaaliset, terveydelliset ja taloudelliset ongelmat kietoutuvat yhteen ja voivat olla vuosien ja vuosikymmenten huono-osaisuuden tulosta (Jones \& Higgs 2015).

Tutkimuksemme teoreettinen tausta kytkeytyy vanhuusiän syrjäytymiseen ja prekaariuden kysymyksiin. Ikääntyvän väestön syrjäytyminen on tunnistettu yhdeksi Euroopan tärkeimmistä sosiaalipoliittisista haasteista (Eu- 
roopan komissio 2010). Syrjäytyminen (social exclusion) on monimutkainen ja moniulotteinen prosessi, johon liittyy resurssien, oikeuksien, tavaroiden ja palvelujen puutetta sekä osattomuutta sellaisista suhteista ja toiminnoista, jotka ovat yhteiskunnan enemmistön saatavilla (Levitas ym. 2007). Syrjäytymisen taustalla on niin yksilö- ja ryhmäkohtaisia olosuhteita kuin rakenteellisia tekijöitä, kuten hyvinvointivaltion roolin heikkeneminen ja palvelujen lisääntyvä yksityistäminen (Walsh ym. 2016).

Syrjäytymisuhan näkökulmasta ikääntyneitä on kansainvälisessä tutkimuksessa yhä useammin alettu väestöryhmänä rinnastaa prekariaatiksi kutsuttuihin nuoriin aikuisiin, joiden elämää leimaavat palkkatyön pirstaleisuus ja toimeentulon ongelmat sekä näistä aiheutuva elämän yleinen epävarmuus, turvattomuus ja näköalattomuus. Eläke- ja palvelujärjestelmät ovat useissa maissa väestön ikääntymisen vuoksi kestävyytensä rajoilla, ja tämä aiheuttaa eläkeikäisillä kasvavaa epävarmuuden ja turvattomuuden tunnetta (esim. Grenier \& Phillipson 2018), erityisesti kun ikääntyessä kroonisten sairauksien ja hoivan tarpeen todennäköisyys kasvaa (Grenier ym. 2017). Prekaariin asemaan liittyy usein elämänkulun myötä kumuloituva taloudellinen ja sosiaalinen niukkuus sekä yhteiskunnan rakenteisiin kytkeytyvä sosiaalisen tuen puute (Grenier \& Phillipson 2018).

Sosiaaliset ongelmat vanhuuden elämänvaiheessa muotoutuvat yhteiskunnallisissa rakenteissa, ajassa ja paikassa tuottaen jatkuvasti uudenlaisia huono-osaisuuden muotoja ja mekanismeja. Pyrimme GERIT-hankkeessa tunnistamaan näitä vanhuusiän moniulotteisen huono-osaisuuden tekijöitä ja edistämään ilmiön teoreettista jäsentämistä. Hanke tuottaa monitieteistä ymmärrystä niiden heikoimmassa asemassa olevien vanhojen ihmisten elämäntilanteista ja tuen tarpeista, jotka usein jäävät tutkimusten ulkopuolelle.

\section{Laaja-alainen laadullinen tieto}

GERIT-tutkimushankkeessa lähestymme kysymyksiä iäkkäiden vaikeista elämäntilanteista, niihin liittyvistä tuen tarpeista sekä tarpeisiin vastaamisesta iäkkäiden ihmisten, ammattilaisten ja muiden toimijoiden sekä asiakasprosessien näkökulmasta. Lähtökohtana on iäkkäiden ihmisten arki ja heidän kanssaan toimivien ihmisten kokemukset. Näiden kokemusten ja näkökulmien tavoittamiseksi hankkeessa kerätään erilaisia laadullisia aineistoja, ja tutkimus nojaakin vahvasti laadulliseen tutkimusperinteeseen.

Aineistoina ovat eri toimijoiden haastattelut sekä asiakirja-aineisto. Asiakirja-aineisto koostuu yhdestä kaupungista kerättävistä gerontologisen sosiaalityön asiakasasiakirjoista. Haastatteluissa tieto muodostuu vuorovaikutuksessa niihin osallistuvien kanssa. Iäkkäitä haastateltavia ovat gerontologisen sosiaalityön asiakkaat sekä diakoniatyön ja erilaisten vapaaehtoistoimijoiden kautta tavoitettavat ikäihmiset. Iäkkäiksi katsotaan 65 vuotta täyttäneet, jolloin haastateltavina voi olla hyvinkin eri-ikäisiä ihmisiä (Lumme-Sandt 2017). Haastattelut tehdään pääosin yksilöhaastatteluina, joko kasvokkain tai puhelimitse. Ryhmähaastatteluihin tai -keskusteluihin (ks. Pietilä 2017) osallistuvat gerontologista sosiaalityötä tekevät sosiaalityöntekijät, muut iäkkäitä julkisessa sosiaalihuollossa kohtaavat työntekijät sekä erilaisissa kolmannen sektorin yhteisöissä toimivat henkilöt. Työntekijä- ja asiantuntijahaastattelut tehdään pandemian vuoksi pääosin etäyhteyksin, mikä voi tarkoittaa perinteisestä ryhmähaastattelusta poikkeavaa vuorovaikutuksen tapaa ja luonnetta. Tutkimuksen tekeminen pandemian aikana tuottaa tarvetta uudenlaisten välineiden käytölle ja myös pohdinnalle siitä, mikä merkitys näillä on tiedon tuottamisessa (ks. esim. Ikonen 2017).

Erilaisten tutkimusaineistojen kautta tavoitteenamme on saada syvällistä ymmärrystä tutkittavasta ilmiöstä. Tätä edistää myös se, että aineistoja kerätään laajalta maantieteelli- 
seltä alueelta: suurkaupunkialueelta, pienemmistä kaupungeista ja haja-asutusalueilta. Näin saadaan laaja-alainen kuva erilaisissa ympäristöissä elävien iäkkäiden ihmisten elämäntilanteista sekä siitä, miten iäkkäiden tuen tarpeita tunnistetaan ja miten niihin vastataan erilaisissa toimintaympäristöissä. Laaja-alaisuus liittyy myös monitieteisyyteen: hankkeessa hyödynnetään sosiaaligerontologista, sosiaalipoliittista sekä sosiaalityön teoriaperinnettä ja käsitteistöä.

Gerontologisen sosiaalityön tietoperustaa vahvistamassa

Vastaamme GERIT-tutkimushankkeessa sosiaalityön kehittämisen ja vanhojen ihmisten monimutkaistuvien elämäntilanteiden haasteeseen. Tieto ikääntyneiden erityisen tuen tarpeisiin liittyvistä taustatekijöistä ja ymmärrys niiden yhteisvaikutuksista iäkkään ihmisen kokonaistilanteessa edistää gerontologisen sosiaalityön tarpeen tunnistamista sekä sosiaalityön piiriin ohjautumista. Hankkeessa tuotetun tutkimustiedon avulla on mahdollista kehittää ja vakiinnuttaa gerontologisen sosiaalityön palveluja sekä erityisosaamista, jolloin kunnissa ja hyvinvointialueilla kyetään vastaamaan vanhojen ihmisten erityisen tuen tarpeeseen sosiaalityön keinoin. Tutkimushankkeen tuottamaa tietoa jalkautetaan laajojen yhteistyöverkostojen, kuten sosiaalialan osaamiskeskusten, seurakuntien ja järjestötoimijoiden, kautta. Tiedotamme hankkeen tuloksista aktiivisesti

\section{Kirjallisuus}

Ahonen K, Kuivalainen S, Liukko J, Nivalainen S, Palomäki LM, Polvinen A, toim. Tutkimuksia eläkeläisten toimeentulokokemuksista ja taloudellisesta hyvinvoinnista. Helsinki: ETK, 2019.

Antikainen-Juntunen E. Psykososiaalinen työ osana gerontologista sosiaalityötä. Gerontologia 2014;28(2):110-6.

Autio T, Soukiala T, toim. GeroMetron kyydissä: ensimmäisen kehittämiskauden tulokset ja oppeja myös sosiaalisessa mediassa ja hankkeen verkkosivuilla. Näin pyrimme varmistamaan, että tieto tavoittaa tutkimuskentän lisäksi kunta- ja muut toimijat. Hankkeesta on tarkoitus tuottaa myös avoimesti saatavilla oleva raportti.

\section{Mia Niemi \\ Helsingin yliopisto}

Tiina Soukiala

Helsingin yliopisto

Eeva Rossi

Lapin yliopisto

Jenna Hirvonen

Itä-Suomen yliopisto

Suvi Ruotsalainen

Itä-Suomen yliopisto

\section{Anne Korpelainen}

Lapin yliopisto

\section{Riitta-Liisa Kinni}

Itä-Suomen yliopisto

Pia Skaffari

Lapin yliopisto

Ilkka Pietilä

Helsingin yliopiston työpaketin johtaja

ilkka.pietila@helsinki.fi

\section{Elisa Tiilikainen}

Itä-Suomen yliopiston työpaketin johtaja elisa.tiilikainen@uef.fi

\section{Minna Zechner}

Lapin yliopiston työpaketin johtaja minna.zechner@ulapland.fi

\section{Marjaana Seppänen}

Helsingin yliopisto, GERIT-hankkeen johtaja marjaana.seppanen@helsinki.fi

Lisätietoa hankkeesta: gerit.fi matkan varrelta. Helsinki: Soccan julkaisuja, 2016.

Euroopan komissio. European Commission. European year for combating poverty and social exclusion Strategic framework document 2010 Internet: https://ec.europa.eu/eurostat/documents/3217494/5723553/KS-EP-09-001-EN. PDF.pdf/beb36abc-ff29-48a0-8518-32b64ad73ca5 (viitattu 3.5.2021). 
Grenier A, Phillipson C, Laliberte D, Hatzifilalithis S, Kobayashi K, Marier, P. Precarity in later life: understanding new forms of risk and insecurity. J Aging Stud 2017; 43:9-14. https://doi.org/10.1016/j.jaging.2017.08.002

Grenier A, Phillipson C. Precarious aging: insecurity and risk in later life. Hastings Center Report 48, 2018.

Helsingin kaupunki. Gerontologisen sosiaalityön yksikön toimintakertomus. Helsingin kaupungilta saatu julkaisematon materiaali, 2019.

Ikonen HM. Puhelinhaastattelu. Teoksessa: Hyvärinen M, Nikander P, Ruusuvuori J, toim. Tutkimushaastattelun käsikirja. Tampere: Vastapaino, 2017:230-43.

Jones IR, Higgs P. Class and health inequalities in later life. In: Formosa M, Higgs P ed. Social class in later life: power, identity and lifestyle. Bristol: Policy Press, 2015:113-32.

Kehusmaa S, Alastalo H, Marjeta N, Mielikäinen L. Asiakasohjaus päättää tulevaisuudessa iäkkään palveluista - työntekijöiden koulutusta pitää lisätä. Helsinki: THL, Tutkimuksesta tiiviisti, 2018; 37.

Kröger T, Karisto A, Seppänen M. Sosiaalityö vanhuuden edessä. Teoksessa: Seppänen M, Kröger T, toim. Vanhuus ja sosiaalityö: sosiaalityö avuttomuuden ja toimijuuden välissä Jyväskylä: PS-kustannus, 2007:7-15.

Kröger T, Van Aerschot L, Mathew PJ. Ikääntyneiden hoivaköyhyys. Yhteiskuntapolitiikka 2019;84(2):124-34.

Laaksonen H. Mistä merkeistä sosiaali- ja terveydenhuollon henkilöstö voi epäillä vanhuksen kaltoinkohtelua? Työelämän tutkimus 2010;8(3):305-8.

Lee EKO, Waites CE. Infusing aging content across the curriculum: innovations in baccalaureate social work education. J Soc Work Educ 2006;42(1):49-66.

https://doi.org/10.5175/JSWE.2006.042110002

Levitas R, Pantazis C, Fahmy E, Gordon D, Lloyd $\mathrm{E}$, Patsios D. The multi-dimensional analysis of social exclusion. Project Report, UniBristol, 2007.

Liikanen HL. Gerontologisen sosiaalityön menetelmiä. Teoksessa: Seppänen M, Karisto A, Kröger T, toim. Vanhuus ja sosiaalityö: sosiaalityö avuttomuuden ja toimijuuden välissä. Jyväskylä: PS-kustannus, 2007:69-91.
Lumme-Sandt K. Vanhojen ihmisten haastattelu. Teoksessa: Hyvärinen M, Nikander P, Ruusuvuori J, toim. Tutkimushaastattelun käsikirja. Tampere: Vastapaino, 2017:297-311.

Pajunen E, Seppänen M, Kuusinen-James K. Vanhussosiaalityö Päijät-Hämeessä. Verson raportteja 2/2009, Lahti: Verso 2009.

Pietilä I. Ryhmäkeskustelu. Teoksessa: Hyvärinen M, Nikander P, Ruusuvuori J, toim. Tutkimushaastattelun käsikirja. Tampere: Vastapaino, 2017: $111-30$.

Pirhonen J, Lolich L, Tuominen K, Jolanki O, Timonen, V. "These devices have not been made for older people's needs" - older adults' perceptions of digital technologies in Finland and Ireland. Technology \& Society 2020;62:e101287. https://doi.org/10.1016/j.techsoc.2020.101287

Ray M, Phillips J. Social work with older people. Basingstoke: Palgrave Macmillan, 2012.

Ray M, Milne A, Beech C, Phillips J, Richards S, Sullivan MP ym. Gerontological social work: reflections on its role, purpose and value. $\mathrm{Br} \mathrm{J} \mathrm{Soc}$ Work 2015;45(4):1296-312.

Ristolainen H, Tiilikainen, E, Rissanen S. Kotona asuvien ikäihmisten palveluohjauksen vaikuttavuus - kuvaileva kirjallisuuskatsaus. Gerontologia 2018;32(2):252-74.

Seppänen M. Gerontologinen sosiaalityö: katsaus lähtökohtiin, nykytilaan ja tulevaisuuteen. Helsinki: Yliopistopaino, 2006.

Seppänen M. Gerontologinen sosiaalityö. Teoksessa: Kananoja A, Lähteinen M, Marjamäki P, toim. Sosiaalityön käsikirja. Helsinki: Tietosanoma, 2016:260-9.

Sosiaalihuoltolaki (1301/2014).

Soukiala T. Sosiaalisen asiantuntijuus gerontologisessa sosiaalityössä. Gerontologia 2015;29(3): 173-80.

STM. Laatusuositus hyvän ikääntymisen turvaamiseksi ja palvelujen parantamiseksi 2020-2023: Tavoitteena ikäystävällinen Suomi. Helsinki: sosiaali- ja terveysministeriö, 2020a.

STM. STM päätti ensimmäisistä yliopistotasoisen sosiaalityön tutkimuksen tutkimusrahoituksista. 2020b. Internet: https://stm.fi/-/stm-paatti-ensimmaisista-yliopistotasoisen-sosiaalityon-tutkimuksen-tutkimusrahoituksista-1 (viitattu 3.5.2021). 
Terveydenhuoltolaki (1326/2010).

Tiilikainen E. Jakamattomat hetket: yksinäisyyden kokemus ja elämänkulku. Gaudeamus, 2019.

Vaalavuo M. Sosiaali- ja terveyspalvelujen merkitys eläkeläisten toimeentulolle. Helsinki: ET, 2018.

Walsh K, Scharf T, Keating N. Social exclusion of older persons: a scoping review and conceptual framework. Eur J Ageing 2016;14(1):8198. https://doi.org/10.1007/s10433-016-0398-8
Yon Y, Mikton CR., Gassoumis ZD, Wilber, KH. Elder abuse prevalence in community settings: a systematic review and meta-analysis. Lancet Glob Health 2017;5(2):147-56. https://doi.org/10.1016/s2214$109 \mathrm{x}(17) 30006-2$ 